\title{
Pengaruh Masa Inkubasi Pupuk dari Air Cucian Beras Terhadap Pertumbuhan Tanaman Sawi Hijau (Brassica juncea L.)
}

\section{Effect Of Fertilizer Incubation Period Of Rice Wash Water On Green Mustard Plant Growth (Brassica juncea L.).}

\author{
Pipit Wijiyanti ${ }^{1 *}$, Endah Dwi Has tuti ${ }^{2}$, Sri Haryanti ${ }^{2}$ \\ ${ }^{1}$ Program Studi Biologi, Departemen Biologi, Fakultas Sains dan Matematika, Universitas Diponegoro \\ ${ }^{2}$ Departemen Biologi Fakultas Sains dan Matematika Universitas Diponegoro \\ Jl. Prof. Soedarto, SH Tembalang Semarang \\ *Email : pipitwiji04@gmail.com
}

Diterima 29 September 2018 / Disetujui 28 Januari 2019

\begin{abstract}
ABSTRAK
Air cucian beras mengandung prote in glutelin dan vitamin B1 yang berpotensi sebagai pupuk organik. Masa inkubasi adalah proses dekomposisi senyawa-senyawa kompleks pada air cucian beras menjadi senyawa sederhana yang dapat dimanfaatkan sebagai pupuk bagi tanaman. Penelitian ini bertujuan untuk mengkaji pengaruh masa inkubasi pupuk dari air cucian beras terhadap pertumbuhan tanaman sawi hijau (Brassica juncea L.). Penelitian dilakukan pada bulan Januari 2018 s/d. bulan April 2018 di Laboratorium Biologi Struktur dan Fungsi Tumbuhan, Departemen Biologi Fakultas Sains dan Matematika Universitas Diponegoro, Semarang. Penelitian ini disusun berdasarkan Rancangan Acak Lengkap (RAL) dengan 5 perlakuan masa inkubasi yang terdiri dari, P0: tanpa masa inkubasi, P1: masa inkubasi 5 hari, P2: masa inkubasi 10 hari, P3: masa inkubasi 15 hari, P4: masa inkubasi 20 hari. Pada penelitian ini parameter yang diamati antara lain, tinggi tanaman, jumlah daun, luas daun, bobot basah tanaman, bobot kering tanaman, jumlah klorofil total dan karotenoid. Data dianalisis menggunakan Analysis of Variance (ANOVA) pada taraf kepercayaan 95\% dan uji lanjut Duncan Multiple Range Test (DMRT). Hasil penelitian menunjukkan bahwa masa inkubasi air cucian beras berpengaruh meningkatkan pertumbuhan tinggi tanaman, bobot basah dan jumlah klorofil total tetapi tidak berpengaruh terhadap pertumbuhan jumlah daun, luas daun, bobot kering dan kandungan karotenoid.
\end{abstract}

Kata kunci :Sawi hijau, air cucian beras, masa inkubasi

\begin{abstract}
Rice wash water contains dissolved nutrients such as glutelin protein and vitamin B 1 which have the potential as an organic fertilizer. The incubation period is the process of decomposing complex compounds in rice wash water into simple compounds that can be used as fertilizer for plants. The research aimed to assess the effect of fertilizer incubation period from rice wash water to the growth of green mustard plants (Brassica juncea L.). The research was conducted in January 2018 to April 2018 at Laboratory of Plant Structure and Functioning Biology, Department of Biology, Faculty of Science and Mathematics, Diponegoro University, Semarang. This research was based on a completely randomized design (CRD) with 5 treatments of incubation period consisting of, P0: without an incubation period, P1: 5 days incubation period, P2: 10 days incubation period, P3: 15 days incubation period, P4: incubation period of 20 days. In this research, the parameters observed were plant height, leaf number, leaf area, wet weight of the plant, dry weight of the plant, total chlorophyll count and carotenoid. Data were analyzed using Analysis of Variance (ANOVA) at 95\% confidence level and continued with Duncan Multiple Range Test (DMRT). The results showed that the incubation period of rice washing water had an effect on increasing the growth of plant height, wet weight, and total chlorophyll but did not affect the growth of leaf number, leaf area, dry weight and carotenoid content.
\end{abstract}

Keywords: green mustard, rice wash water, an incubation period 


\section{PENDAHULUAN}

Sawi hijau (Brassica juncea L.) merupakan sayuran yang memiliki nilai ekonomis cukup tinggi, dan menjadi salah satu komoditas sayuran yang cukup popular di Indonesia (Wahid $d k k$., 2013). Konsumennya mulai dari golongan masyarakat kelas bawah hingga golongan masyarakat kelas atas, sehingga permintaan akan sawi dari hari ke hari semakin meningkat (Nurshanti, 2010). Tingginya tingkat konsumsi dan permintaan pasar terhadap sawi hijau tidak diimbangi dengan tingkat produksi sawi hijau yang dilakukan oleh para petani sayur di Indonesia. Salah satu faktor penyebab rendahnya produksi sawi hijau yaitu, penggunaan pupuk anorganik yang berlebihan dan dilakukan secara terus menerus dalam jangka waktu yang panjang oleh sebagian besar petani sayur di Indonesia, sehingga dapat berpengaruh pada tingkat kesuburan tanah, yang berakibat pada hilangnya unsur hara dalam tanah. Salah satu solusi yang dapat dilakukan agar ketersediaan unsur hara tetap terjaga perlu dilakukan pemupukan menggunakan pupuk organik.

Pupuk organik adalah pupuk yang diproses dari limbah organik seperti kotoran hewan, sampah, sisa tanaman, serbuk gergajian kayu, lumpur aktif, yang kualitasnya tergantung dari proses atau tindakan yang diberikan (Yulipriyanto, 2010). Salah satu sumber yang dapat dijadikan sebagai pupuk organik untuk memperbaiki unsur hara tanah adalah pupuk organik yang dibuat dari limbah air cucian beras. Air cucian beras mengandung banyak nutrisi yang terlarut didalamnya diantaranya adalah protein, $80 \%$ vitamin B1, $50 \%$ fosfor, dan $60 \%$ zat besi. Protein dan vitamin B1 (thiamin) yang terkandung dalam air cucian beras pada tanaman memiliki peranan yang penting untuk pertumbuhan dan perkembangan tanaman (Bahar,2016). Protein merupakan sumber utama unsur $\mathrm{N}$ yang berperan penting untuk pertumbuhan vegetatif pada tanaman, sedangkan vitamin B1, berfungsi sebagai koenzim dalam metabolisme karbohidrat serta meningkatkan aktivitas hormon yang terdapat dalam jaringan tanaman, untuk mendorong pembelahan sel-sel baru (Amalia $d k k$., 2013).
Untuk menjadikan air cucian beras sebagai pupuk organik cair, perlu adanya perlakuan tertentu melalui masa inkubasi, tujuannya untuk mendekomposisi senyawa komplek pada air cucian beras menjadi senyawa yang lebih sederhana, sehingga saat digunakan sebagai pupuk dan diaplikasikan pada tanaman akan mudah diserap. Masa inkubasi sangat menentukan kematangan dari suatu pupuk, apabila masa inkubasi belum cukup, maka pupuk yang dihasilkan kualitasnya kurang baik bila digunakan (Fathini $d k k ., 2014$ ).

Berkaitan dengan hal tersebut, menurut hasil penelitian dari Handayani $d k k$., (2015), mengatakan bahwa air cucian beras dapat dijadikan sebagai pupuk organik cair sesuai dengan standar mutu pupuk organik cair, setelah dilakukan fermentasi selama 15 hari, pada waktu tersebut kandungan unsur hara setelah fermentasi 15 hari mengalami peningkatan. Beberapa penelitian lainnya juga menunjukkan bahwa air cucian beras yang disimpan selama 2 minggu pada beberapa jenis tanaman dapat menggantikan pupuk anorganik (Elfarisna, dkk., 2013). Berdasarkan uraian di atas, penelitian ini dilakukan untuk mengetahui pengaruh masa inkubasi yang berbeda dari air cucian beras terhadap pertumbuhan sawi hijau (Brassica juncea L.).

\section{METODE PENELITIAN}

Penelitian ini dilaksanakan di Laboratorium Biologi Struktur dan Fungsi Tumbuhan, Departemen Biologi Fakultas Sains dan Matematika, Universitas Diponegoro. Bahan yang digunakan dalam penelitian ini adalah air cucian beras, molase, EM4, air, bibit tanaman sawi hijau, tanah, pupuk kandang, aseton $80 \%$, dan kertas saring.

\section{Pembuatan Pupuk Air Cucian Beras}

Pembuatan pupuk dilakukan setiap lima hari sekali. Proses pembuatan pupuk diawali dengan menimbang beras sebanyak 250 gr, selanjutnya di cuci dengan air sebanyak $500 \mathrm{ml}$, dan dilakukan sebanyak 3 kali sehingga diperoleh $1500 \mathrm{ml}$ air cucian beras, kemudian air cucian 
beras dicampur dan ditambahkan dengan molase dan EM4 dengan konsentrasi $100 \mathrm{ml}$, selanjutnya diaduk sampai homogen dan dimasukkan ke dalam botol plastik dan di inkubasi selama masa inkubasi tertentu yaitu tanpa masa inkubasi (0 hari), masa inkubasi 5 hari, 10 hari, 15 hari dan 20 hari.

\section{Analisis Kandungan Hara N dan P}

Analisis kandungan hara $\mathrm{N}$ pada pupuk air cucian beras dengan masa inkubasi berbeda dilakukan dengan menggunakan metode Kjeldahl, dan analisis kandungan $\mathrm{P}$ dilakukan dengan metode spektrofotometri.

\section{Parame ter Pengamatan}

Pengamatan dilakukan setelah tanaman sawi hijau berumur 45 hari setelah tanam, yang meliputi: tinggi tanaman $\left(\mathrm{cm}^{2}\right)$, jumlah daun (helai), luas daun $\left(\mathrm{cm}^{2}\right)$, bobot basah (g), bobot kering $(\mathrm{g})$, jumlah klorofil total $(\mu \mathrm{mol})$ dan karotenoid ( $\mu \mathrm{mol})$.

\section{HASIL DAN PEMBAHASAN}

\section{Kandungan Hara $\mathbf{N}$ dan $\mathbf{P}$}

Hasil analisis kandungan hara $\mathrm{N}$ dan $\mathrm{P}$ pada pupuk air cucian beras dengan masa inkubasi berbeda berdasarkan Tabel 1, kandungan $\mathrm{N}$ tertinggi terdapat pada perlakuan P3 (inkubasi 15 hari) sebesar $0,07 \%$, dan yang terendah terdapat pada perlakuan P1 dan $\mathrm{P} 4$ dengan kandungan $\mathrm{N}$ 0,04\%. Demikian juga dengan kandungan unsur $P$, perlakuan P2 dan P3 memiliki kandungan $\mathrm{P}$ tertinggi yaitu $0,06 \%$, dan pada perlakuan $\mathrm{P} 1$ memiliki kandungan $\mathrm{P}$ terendah dibandingkan dengan perlakuan lainnya yaitu hanya $0,03 \%$.

Tabel 1. Hasil analisis $\mathrm{N}$ dan $\mathrm{P}$ pada pupuk air cucian beras $0,5,10,15$ dan 20 hari inkubasi

\begin{tabular}{lccccc}
\hline \multicolumn{5}{c}{ Perlakuan } \\
\hline Parameter & P0 & P1 & P2 & P3 & P4 \\
& $(0$ hari $)$ & $(5$ hari $)$ & $(10$ hari $)$ & $(15$ hari $)$ & $(20$ hari $)$ \\
N-Total (\%) & 0,06 & 0,04 & 0,05 & 0,07 & 0,04 \\
P0O5 (\%) & 0,04 & 0,03 & 0,06 & 0,06 & 0,04 \\
\hline
\end{tabular}

Berdasarkan Tabel 1, kandungan hara $\mathrm{N}$ dan $\mathrm{P}$ yang berbeda pada masing-masing perlakuan disebabkan oleh masa inkubasi. Menurut Cesaria $d k k$., (2014), inkubasi adalah penguraian unsur organik kompleks terutama karbohidrat untuk menghasilkan energi melalui reaksi enzim yang dihasilkan oleh mikroorganisme yang biasanya terjadi dalam keadaan anaerob dan diiringi dengan pembebasan gas. Hasil analis is kandungan hara $\mathrm{N}$ dan $\mathrm{P}$, pada masa inkubasi 15 hari memiliki kandungan $\mathrm{N}$ tertinggi dibandingan perlakuan lainnya, karena komponen yang terkandung pada air cucian beras telah didekomposisi dengan sempurna oleh mikroba dan juga masa inkubasi 15 hari menyebabkan tingkat kematangan yang tepat pada pupuk. Hasil lainnya pada perlakuan tanpa masa inkubasi ( 0 hari), juga memiliki kandungan $\mathrm{N}$ yang tinggi, karena dalam air cucian beras segar sudah terdapat kandungan komponen $\mathrm{N}$ terlarut dalam jumlah yang tinggi.

Nitrogen terlarut yang terdapat pada perlakuan 0 hari, kemungkinan berasal dari butiran aleuron yang seringkali ikut terkikis ketika mencuci beras sebelum diolah menjadi nasi yang berupa $\mathrm{N}$ organik dan terdiri dari komponen protein. Menurut Jorgensen (2009), nitrogen terlarut didefinisikan sebagai material yang berukuran kurang dari $0,2 \mu \mathrm{m}$, yang di dalamnya terdapat molekul organik dan senyawa seperti urea, asam amino dan protein. Effendi (2003), juga mengatakan bahwa, nitrogen merupakan senyawa kimia yang terdiri dari nitrogen organik dan anorganik. N-organik terdiri dari protein, asam anino dan urea, dimana senyawa $\mathrm{N}$-organik tersebut selanjutnya dapat ditransformasi menjadi $\mathrm{NH}_{4}{ }^{+}$dan dioksidasi menjadi $\mathrm{NO}_{3}{ }^{-}$dan $\mathrm{NO}_{2}{ }^{-}$. 


\section{Tinggi Tanaman}

Berdasarkan hasil analisis statistika, pemberian pupuk air cucian beras dengan masa inkubasi berbeda dapat berpengaruh nyata terhadap tinggi tanaman. Pertumbahan tinggi tanaman merupakan salah satu bentuk adanya peningkatan pembelahan dalam meristem apikal, sehingga mendorong terjadinya pertumbuhan primer. Berdasarkan Gambar 1, tinggi tanaman pada perlakuan P3 memberikan hasil terbaik dan tidak berbeda nyata dengan P0 dan P4. Hal ini karena pemberian pupuk air cucian beras pada perlakuan tersebut mampu mensuplai unsur hara $\mathrm{N}$ yang cukup bagi pertumbuhan tanaman.

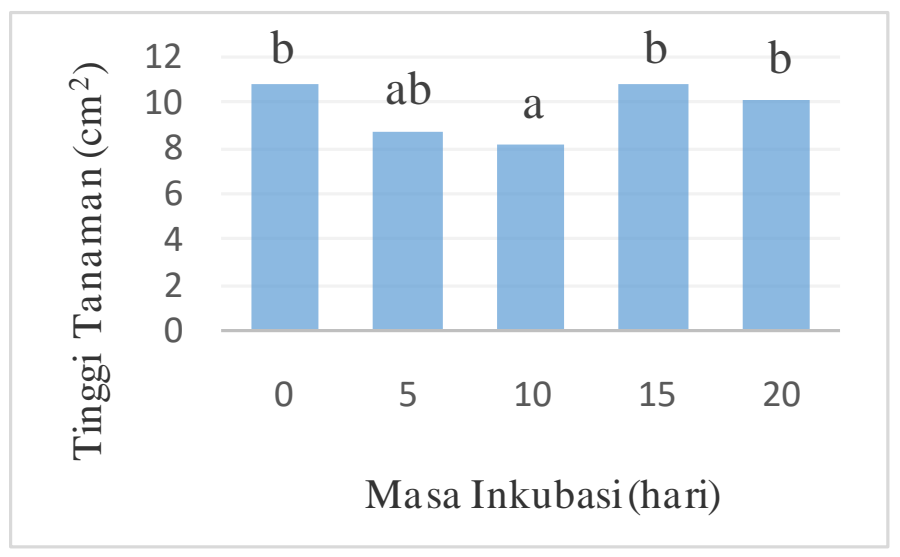

Gambar 1. Rerata Pertambahan Tinggi Tanaman Sawi Hijau

Menurut Sari $d k k$., (2017), proses pembelahan sel akan berjalan dengan cepat dengan adanya ketersediaan $\mathrm{N}$ yang cukup. Unsur $\mathrm{N}$ mempunyai peran utama untuk merangsang pertumbuhan secara keseluruhan dan khususnya pertumbuhan batang yang dapat memacu pertumbuhan tinggi tanaman. Menurut Fathini $d k k . .$, (2014), mengatakan kandungan unsur hara, seperti $\mathrm{N}$ dan $\mathrm{P}$ dalam pertumbuhan tanaman sangat penting sehingga ketersediaanya harus sesuai dengan kebutuhan dari tanaman itu sendiri, dan untuk pertumbuhan tanaman khususnya pertumbuhan vegetatif, nitrogen dibutuhkan dalam jumlah yang besar untuk setiap tahapan pertumbuhan tanaman. Fahmi $d k k$., (2010), juga mengatakan bahwa unsur hara nitrogen dan fosfor merupakan unsur hara yang sangat dibutuhkan oleh tanaman dalam jumlah yang besar, apabila tanaman kekurangan nitrogen pertumbuhannya menjadi lambat, dan tanaman menjadi kerdil, sementara kekurangan fosfor menyebabkan perakaran tidak berkembang dengan baik, dan pertumbuhan tanaman menjadi terhambat.

\section{Jumlah Daun}

Berdasarkan hasil analisis statistika pemberian pupuk air cucian beras tidak memberikan pengaruh yang nyata pada jumlah daun tanaman sawi hijau. Gambar 2, menunjukkan adanya kecenderungan perlakuan tanpa masa inkubasi (0 hari) dan dengan inkubasi 15 hari memiliki jumlah daun terbanyak dibandingkan dengan perlakuan lainnya.

Daun merupakan organ tanaman tempat mensintesis makanan untuk kebutuhan tanaman maupun sebagai cadangan makanan (Duaja, 2012). Nutrisi sangat berpengaruh pada pembentukan daun terutama unsur N. Kandungan hara $\mathrm{N}$ yang tinggi pada masa inkubasi 0 hari dan 15 hari, menyebabkan jumlah daun yang tumbuh semakin bertambah. Ikhtiyanto (2010), mengatakan bahwa unsur $\mathrm{N}$ berperan untuk pertumbuhan vegetatif, yaitu pembentukan tunas, pembentukan daun, dan pertumbuhan batang, apabila pasokan $\mathrm{N}$ tersedia dalam jumlah yang cukup, daun tanaman akan tumbuh besar dan memperluas permukaan yang tersedia untuk proses fotosintesis. 


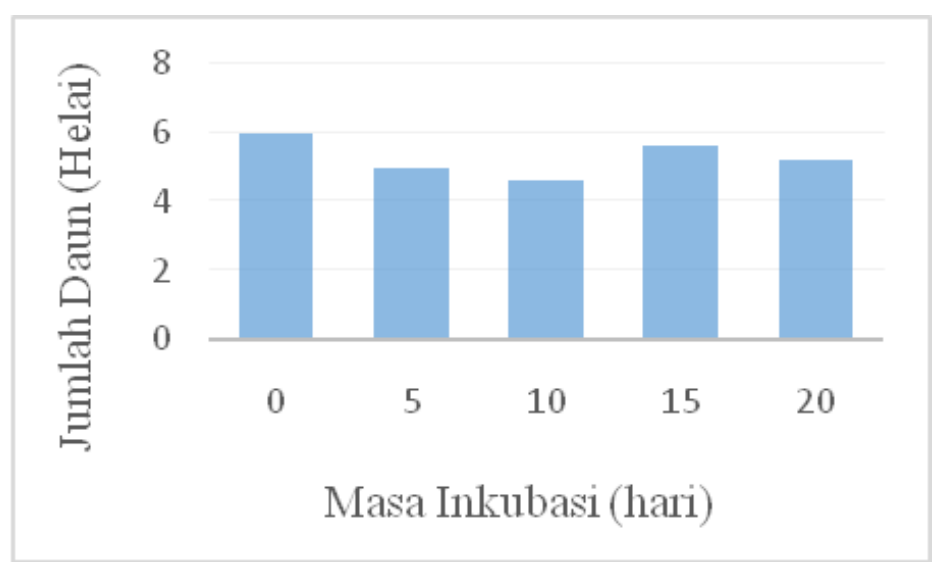

Gambar 2. Rerata Jumlah Daun Tanaman Sawi Hijau

\section{Luas Daun}

Berdasarkan hasil analisis statistika, perlakuan pemberian pupuk air cucian beras dengan masa inkubasi berbeda tidak berpengaruh terhadap luas daun tanaman sawi hijau. Hasil rerata luas daun dapat dilihat pada Gambar 3. Meskipun masa inkubasi tidak berpengaruh tetapi ada kecenderungan pada perlakuan tanpa masa inkubasi (0 hari) memiliki luas daun tertinggi dibandingkan dengan perlakuan lainnya.Daun merupakan organ penting tanaman yang berperan dalam proses fotosintesis karena terdapat klorofil. Luas daun dari setiap tanaman, umumnya dipengaruhi oleh jumlah daun. Semakin banyak jumlah daun maka luas daun dari suatu tanaman juga semakin lebar. Ifantri dan Ardiyanto (2015), menyatakan bahwa suatu tanaman semakin banyak jumlah daunnya maka luas daunnya akan semakin lebar.

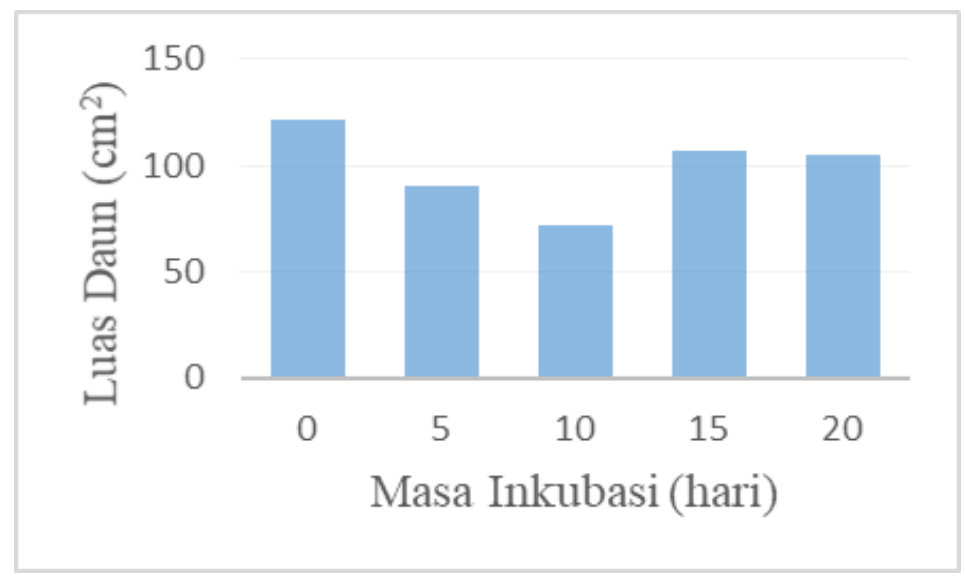

Gambar 3. Rerata Luas Daun Tanaman Sawi Hijau

\section{Bobot Basah dan Bobot Kering}

Berdasarkan hasil analisis statistika terdapat pengaruh yang nyata pada bobot basah sawi hijau tetapi tidak pada bobot kering. Gambar 4 menunjukkan rerata bobot basah dan bobot kering tertinggi terdapat pada perlakuan pemberian pupuk air cucian beras tanpa masa inkubasi ( 0 hari).

Bobot basah dan bobot kering dari suatu tanaman dipengaruhi oleh ketersediaan unsur hara $\mathrm{N}$ yang cukup untuk membantu meningkatkan pertumbuhan tanaman seperti pertumbuhan tingg $\mathrm{i}$ 
tanaman dan pembentukan daun. Ardiansyah (2013), mengatakan bahwa, faktor ketersediaan unsur hara dapat berpengaruh pada pertumbuhan dan perkembangan tanaman, sehingga berpengaruh pada berat segar tanaman. Harjadi (2007), juga mengatakan bahwa ketersediaan unsur hara berperan penting dalam mempengaruhi biomassa dari suatu tanaman.

Bobot basah dan bobot kering terdiri atas semua bagian tanaman sawi hijau. Semakin banyak daun maka bobot basah dan bobot kering tanaman juga akan meningkat. Tinggi tanaman juga berpengaruh pada bobot basah tanaman. Semakin tinggi tanaman sawi hijau dan semakin banyak jumlah daunnya, maka bobot basah juga akan meningkat. Nurdin (2011) mengatakan jumlah daun dapat berpengaruh terhadap peningkatan bobot kering tanaman karena daun merupakan tempat akumulasi hasil fotosintat tanaman. Menurut Ardiansyah (2013), juga menyatakan bahwa hasil berat kering merupakan keseimbangan antara fotosintesis dan respirasi.

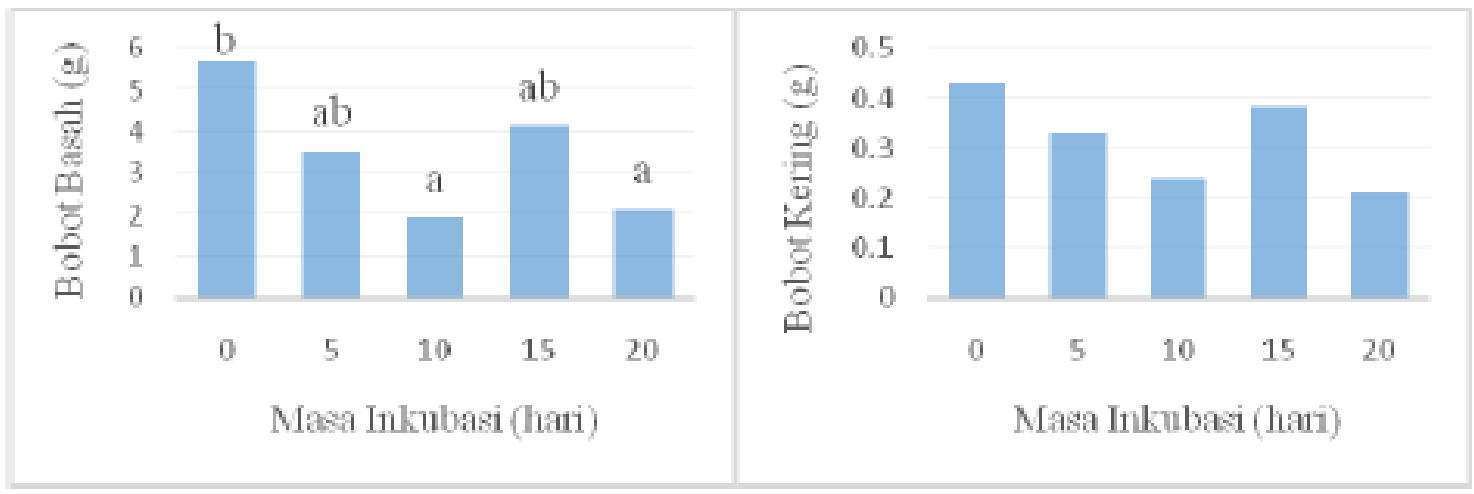

Gambar 4. Rerata Bobot Basah dan bobot kering Tanaman Sawi Hijau

\section{Jumlah Klorofil dan Karotenoid}

Hasil analis is statistika, pemberian pupuk air cucian beras dengan masa inkubasi berbeda dapat berpengaruh terhadap jumlah klorofil total

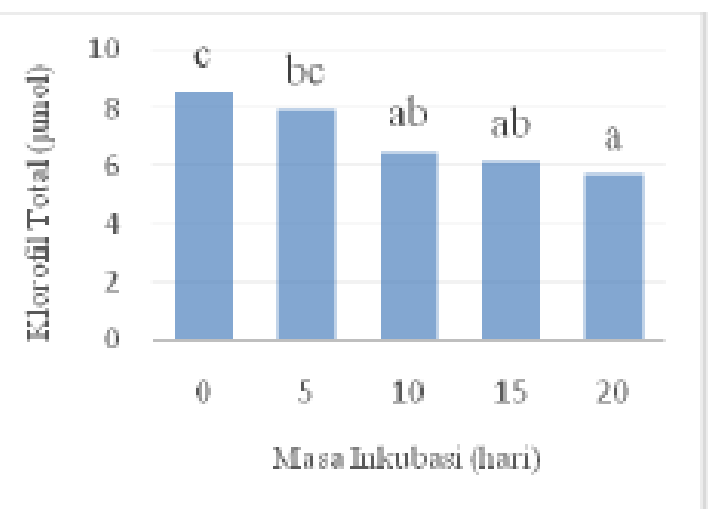

dari tanaman sawi hijau (Brassica juncea L.) tetapi tidak berpengaruh pada jumlah karotenoid. Gambar 5, menunjukkan semakin lama masa inkubasi jumlah klorofil total dan karotenoid semakin menurun.

\section{Gambar 5. Rerata Jumlah Klorofil Total dan Karotenoid Tanaman Sawi Hijau}

Pembentukan pigmen klorofil maupun karotenoid pada tanaman dapat dipengaruhi oleh beberapa faktor, salah satunya dari ketersediaan unsur hara. Unsur hara dalam proses fotosintesis memiliki peranan yang penting untuk pembentukan protein dan klorofil, khususnya hara N. Menurut Setyanti $d k k$.,(2013), nitrogen menjadi bagian dari molekul klorofil yang mengendalikan kemampuan tanaman 
dalam melakukan fotosintesis. Nitrogen berperan sebagai penyusun pigmen klorofil.

Penurunan jumlah klorofil dan karotenoid pada tanaman sawi karena adanya kompetisi penggunaan unsur $\mathrm{N}$ dan $\mathrm{P}$ untuk pertumbuhan tanaman dan pembentukan klorofil. Kandungan $\mathrm{N}$ dan $\mathrm{P}$ yang terdapat pada setiap perlakuan lebih dioptimalkan oleh tanaman sawi untuk mempercepat pertumbuhan tinggi tanaman, meningkatkan jumlah anakan dan membuat tanaman menjadi besar, sehingga pasokan $\mathrm{N}$ untuk pembentukan klorofil menjadi lebih sedikit.

\section{KESIMPULAN}

Masa inkubasi pada pupuk air cucian beras berpengaruh nyata terhadap pertumbuhan tinggi tanaman, bobot basah dan jumlah klorofil total tetapi tidak berpengaruh nyata terhadap jumlah daun, luas daun, bobot kering dan jumlah karotenoid tanaman sawi hijau (Brassica juncea L.). Pertumbuhan tanaman sawi hijau (Brassica juncea L.), perlakuan masa inkubasi 15 hari, memberikan hasil terbaik pada parameter tinggi tanaman. Perlakuan 0 hari memberikan hasil terbaik pada parameter jumlah daun, luas daun, bobot basah, dan bobot kering tanaman sawi hijau (Brassica juncea L.). Masa inkubasi yang semakin lama justru menghambat pembentukan pigmen klorofil dan karotenoid dari tanaman sawi hijau (Brassica juncea L.).

\section{DAFTAR PUSTAKA}

Amalia Riska, Tutik Nurhidayati, dan Siti Nurfadilah. 2013. Pengaruh Jenis dan Konsentrasi Vitamin terhadap Pertumbuhan dan Perkembangan Biji Dendrobium laxiflorum J.J Smith secara In Vitro. Jurnal Sains Dan Seni Pomits Vol. 1, No. 1, (2013) 1-6.

Ardiansyah, M. 2013. Respons Pertumbuhan dan Produksi Kedelai Hasil Seleksi Terhadap Pemberian Asam Askorbat dan Inokulasi Fungi Mikoriza Arbuskulardi Tanah Salin. Universitas Sumatera Utara, Medan

Bahar Angga Elya. 2016. Pengaruh Pemberian Limbah Air Cucian Beras Terhadap
Pertumbuhan Tanaman Kangkung darat (Ipomoea reptans poir). Skripsi. Program Studi Agroteknologi Fakultas Pertanian Universitas Pasir Pengaraian.

Cesaria, Rizki Yunia., Ruslan Wirosoedarmo., Bambang Suharto. 2014. Pengaruh Penggunaan Starter Terhadap Kualitas Fermentasi Limbah Cair Tapioka Sebagai Alternatif Pupuk Cair. Jurnal Sumberdaya Alam dan Lingkungan

Duaja Made Devani. 2012. Pengaruh Bahan dan Dosis Kompos Cair Terhadap Pertumbuhan Selada (Lactuca sativa sp.). Jurnal Agroteknologi, Vol 1 No.1, ISSN: 2302-6472

Effendi, H. 2003. Telaah Kualitas Air Bagi Pengelolaan Sumber Daya dan Lingkungan Perairan. Kanasius. Yogyakarta

Elfarisna, Puspita, R.T., Mardani M. 2013. Kombinasi Penggunaan Berbagai Dosis Air Limbah Cucian Beras Dengan Miza Plus Terhadap Pertumbuhan Dan Produksi Kedelai Edamame (Glycine max L.). Prosiding Seminar Nasional Hasil Penelitian Tanaman Kacang-Kacangan Dan Umbi-Umbian, Balitbang. Malang

Fahmi Arifin., Syamsudin.,Sri Nuryani H.U., Bostang Radjagukguk. 2010. The Effect of Interaction of Nitrogen and Phosphorus Nutrients on Maize (Zea Mays L) Grown In Regosol and Latosol Soils. Byologic News 10(3)

Fathini Dannar Nur., Sriyanto Waluyo., Suci Handayani. 2014. Pengaruh Masa Inkubasi Vinasse dan Takaran Pupuk Kalium Terhadap Pertumbuhan dan Hasil Cabai Merah (Capsicum Annum L.). Vegetalika Vol.3 No.2, 2014: 13 - 24

Handayani Sri Hesti., Ahmad Yunus., dan Ari Susilowati. 2015. Uji Kualitas Pupuk Organik Cair Dari Berbagai Macam Mikroorganisme Lokal (MOL). Jurnal ELVIVO Vol.3, No.1, hal 54-60.

Harjadi, B. 2007. Analisis Karakteristik Kondisi Fisik Lahan DAS dengan PJ dan SIG di DAS Benain-Noemina, NTT. Jurnal Ilmu 
Tanah dan Lingkungan Vol.7 No.2 p:7479

Ifantri Johan dan Ardiyanto. 2015. The Effect Of Number Of Leaves And The Type Of Manure On The Growth And Yield Of Melon (Cucumis melo L.), Fakultas Pertanian, Universitas PGRI. Yogyakarta

Ikhtiyanto Rifka Ernawan. 2010. Pengaruh Pupuk

Nitrogen Dan Fosfor Terhadap Pertumbuhan Dan Produksi Tebu (Sacharum officinarum L.). Skripsi. Departemen Agronomi Dan Hortikultura Fakultas Pertanian Institut Pertanian Bogor. Bogor

Jorgensen N.O.G. 2009. Organic Nitrogen. University of Copenhagen, Fredericksberg, Denmark. Elsevier Inc.

Nurdin. 2011. Penggunaan Lahan Kering di Das Limboto Provinsi Gorontalo untuk Pertanian Berkelanjutan. Jurnal Litbang Pertanian 30(3): $98-107$.

Nurshanti, Dora Fatma. 2010. Pertumbuhan dan Produksi Tanaman Sawi (Brasicca juncea L) dengan Tiga Varietas Berbeda. AgronobiS, Vol. 2, No.4, September, ISSN: $1979-8245 X$

Sari, Nawang Vinda., Same Made.,Yonathan Parapasan. 2017. Pengaruh Konsentrasi dan Lama Fermentasi Urin Sapi sebagai Pupuk Cair pada Pertumbuhan Bibit Karet (Hevea brasiliensis Muell. Arg.). Jurnal Agro Industri Perkebunan Volume 5 No.1: 57-71

Setyanti, Y. H., Anwar S., dan Slamet. 2013. Karakteristik Fotosintetik Dan Serapan Fosfor Hijauan Alfalfa (Medicago Sativa) Pada Tinggi Pemotongan Dan Pemupukan Nitrogen Yang Berbeda. Animal Agriculture Journal Vol. 2. No. 1, p 86 96

Wahid, Tenri Sa'na., Andi Ilham Latunraa., Baharuddin dan Andi Masniawatia. 2013. Optimalisasi Pertumbuhan Dan Produksi Tanaman Sawi Hijau (Brassica juncea L.) Secara Hidroponik Dengan Pemberian Berbagai Bahan Organik Cair. [Artikel ilmiah]. Jurusan Biologi FMIPA
Universitas Hasanuddin, Fakultas

Pertanian Universitas

Hasanuddin.Makassar

Yulipriyanto, H. 2010. Biologi Tanah dan Strategi Pengelolaannya. Graha Ilmu. Yogyakarta 